\title{
MENDORONG EKONOMI DAERAH KALIMANTAN TIMUR MELALUI EKSPOR KOMODITAS OLAHAN CPO DAN BATU BARA
}

\author{
Vahri Firmansyah \\ Kanwil Bea Cukai Kalimantan Bagian Timur, Indonesia \\ Email : vfirmansyah90@gmail.com
}

Manuskrip: Desember -2021; Ditinjau: Januari -2022; Diterima: Januari -2022;

Online: Januari-2022; Diterbitkan: Januari-2022

\begin{abstract}
ABSTRAK
Saat ini banyak perusahaan yang mengeksplorasi Sumber Daya Alam di Kalimantan Timur, seperti olahan CPO dan batu bara. Bisnis ini diharapkan memberikan dampak untuk memajukan perekonomian regional di daerah ini. Bukti empiris mutlak diperlukan untuk melihat sejauh mana sumbangsih industri ini bagi masyarakat sekitar. Metode analisis statistik yang digunakan adalah regresi linear berganda dengan kombinasi metode interpolasi untuk memenuhi konsistensi data. Hasilnya ekspor komoditas olahan CPO dan batu bara memberi dampak yang signifikan terhadap PDRB, dengan catatan batu bara memiliki efek peningkatan PDRB lebih besar. Hal ini menjadi menarik karena hanya CPO dan produk turunannya yang dipungut Bea Keluar menurut PMK 166/PMK.10/2020. Hasil penelitian diharapkan memberi perspektif baru khususnya bagi pemerintah melalui Bea Cukai untuk mendorong ekspor komoditas ini, salah satunya melalui pemberian fasilitas seperti Gudang Berikat (GB), Pusat Logistic Berikat (PLB), Kawasan Berikat (KB) maupun Kemudahan Impor Tujuan Ekspor (KITE) dengan tetap mengoptimalkan pengawasan.
\end{abstract}

\section{Kata Kunci: Ekspor, CPO, Batu Bara, PDRB}

\section{PENDAHULUAN}

Kalimantan dengan segala potensi sumber daya alam menjadi tempat yang menjanjikan untuk berinvestasi. Pengembangan industri hilir dengan berbasis pengolahan sumber daya alam menjadi kekuatan utama dalam menggerakkan perekonomian. Banyak perusahaan yang akhirnya mendapatkan keuntungan luar biasa dari berbisnis di tanah khatulistiwa. Ekspor menjadi orientasi penjualan yang utama perusahaan dalam memasarkan produknya. Diharapkan ada kontribusi ke negara baik dari Bea Keluar, Pajak maupun PNBP yang dipungut. Selain itu industri disini juga menyerap tenaga kerja yang cukup besar. Hal ini mewakili ekpektasi kita bahwa roda ekonomi di daerah akan bergulir dengan cepat.

Seperti yang kita tahu pandemi membuat pertumbuhan ekonomi mengalami kontraksi yang cukup dalam, bahkan sampai minus 2,07 pada tahun 2020. Akan tetapi ekspor beberapa komoditas mengalami pertumbuhan yang positif seperti olahan CPO dan batu bara. Ekspor olahan minyak sawit pada bulan Mei 2021 
menjadi rekor bulanan tertinggi sepanjang sejarah yaitu sebesar US\$ 3,063 milliar (Timmoria, 2021). Kemudian batu bara juga mengalami peningkatan permintaan khususnya dari luar negeri. Kalimantan Timur menjadi salah satu daerah yang menjadi penyumbang ekspor olahan CPO dan batu bara terbesar di Indonesia. Menurut data dari bidang kepabeanan dan cukai perusahaan olahan CPO dan perusahaan batu bara tersebar di Kalimantan Timur. Salah satu kegiatannya adalah refinery CPO menjadi produk turunannya seperti RBDPO dan produk sampingan PFAD.

Direktorat Jenderal Bea Cukai melalui Kantor Wilayah Kalimantan Bagian Timur memfasilitasi kegiatan ekspor di kawasan Kalimantan Timur. Kantor Wilayah Kalbagtim membawahi KPPBC Balikpapan, KPPBC Nunukan, KPPBC Bontang, KPPBC Tarakan, KPPBC Samarinda dan KPPBC Sangata dalam memberikan asistensi bagi industri dalam melakukan kegiatan ekspor. Peran bea cukai sebagai Industrial Asistence sangat penting dalam mendorong ekspor di Kalimantan Timur. Salah satunya dengan memberikan fasilitas fiskal kepada industri yang sudah memenuhi ketentuan yang berlaku. Fasilitas yang diberikan seperti Gudang Berikat, Pusat Logistik Berikat, Kawasan Berikat, dan KITE. Perusahaan yang mendapat fasilitas ini dapat diberi penangguhan bea masuk, pembebasan cukai, tidak dipungut PDRI dan tidak dipungut PPN.

Menurut data pada bidang kepabeanan dan cukai Kantor Wilayah Kalimantan Bagian Timur mulai tahun 2017 sampai kuartal 2 tahun 2021 PT Kaltim Prima Coal menjadi eksportir batu bara tertinggi. Nilai devisa ekspor mencapai USD 14,260,141,552.36 dengan tonase 227.44(JT TON). Sementara itu PT Kutai Refinery Nusantara menjadi eksportir olahan CPO dengan nilai ekspor tertinggi. Nilai devisa ekspornya mencapai USD 3,379,771,933.71 dengan tonase 4.36 (JT TON). Negara tujuan ekspor dari batu bara diantaranya China, India, Jepang, Korea, Malaysia. sedangkan tujuan ekspor CPO adalah China, Malaysia, Pakistan, Filipina dan Kenya. Bahkan pada bulan Agustus tahun ini ekspor ke Kenya naik sangat signifikan.

Grafik 1. Bea Keluar CPO dan Turunannya BC Kalbagtim Jan-Okt 2021

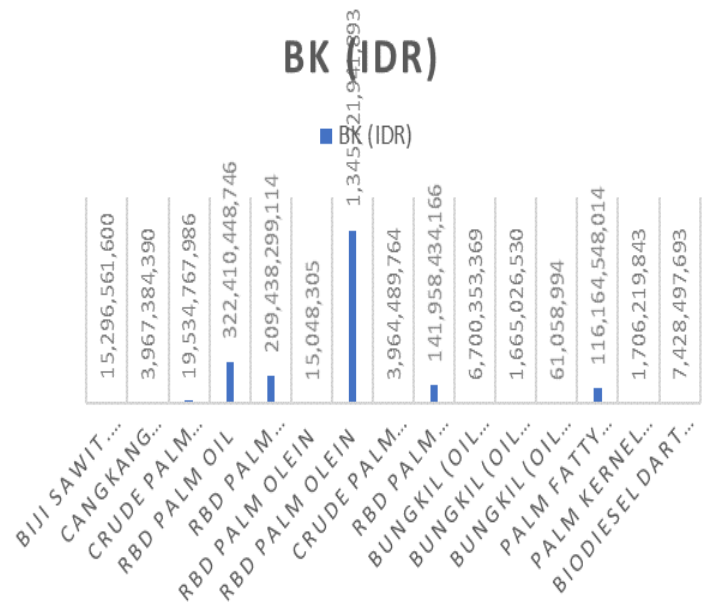

Sumber: Bidang Kepabeanan dan Cukai (diolah), 2021 
Dari grafik di atas dapat dilihat penerimaan negara dari Bea Keluar dari produk olahan CPO di Kalimantan Timur cukup tinggi, sedangkan batu bara memang selama ini tidak dipungut Bea Keluar pada kegiatan ekspornya. Menurut PMK 166/PMK.10/2020 tercatat saat ini olahan CPO mempunyai tarif spesifik, dengan nilai tertinggi adalah CPO murni dengan Bea Keluar USD 200/MT. Berdasarkan pengamatan penulis selama berdinas di Kalimantan Barat dan Kalimantan Timur situasi ekonomi di Kalimantan belum merata dibuktikan dengan infrastruktur yang relatif tertinggal dari kota besar di Jawa. Idealnya banyak kegiatan industri di Kalimantan Timur seharusnya merangsang pertumbuhan ekonomi di daerah sehingga memajukan masyarakatnya. Indikator pertumbuhan ekonomi regional dapat dilihat dari Produk Domestik Regional Bruto (PDRB). Kemudian apakah komoditas olahan CPO yang secara langsung menyumbang penerimaan negara memberi dampak yang sama dengan batu bara (tidak dipungut Bea Keluar). Menurut data yang ada nilai devisa ekspor batu bara lebih besar daripada olahan CPO. Hal ini menjadi menarik untuk melihat potensi masing masing komoditas dalam meningkatkan ekonomi regional Kalimantan Timur.

\section{Rumusan Masalah}

Rumusan masalah dalam penelitian ini adalah sebagai berikut:

1. Apakah nilai devisa ekspor olahan CPO dan ekspor batu bara dari industri hilir di Kalimantan Timur memberikan pengaruh peningkatan PDRB?

2. Apakah ada perbedaan dari ekspor komoditas olahan CPO yang dipungut Bea Keluar dengan komoditas batu bara (sampai saat ini belum dikenakan Bea Keluar) terhadap peningkatan PDRB di Kalimantan Timur?

\section{Tujuan penelitian}

Adapun tujuan dari penelitian ini adalah:

1. Menganalisis dampak ekspor olahan CPO dan ekspor batu bara dari industri hilir di Kalimantan Timur terhadap peningkatan PDRB

2. Menganalisis dampak dari ekspor komoditas olahan CPO yang dipungut Bea Keluar dengan komoditas batu bara (sampai saat ini belum dikenakan Bea Keluar) terhadap peningkatan PDRB di Kalimantan Timur

\section{Tinjuan Pustaka}

Dalam ilmu ekonomi regional teori pusat pertumbuhan ekonomi dinyatakan sebagai salah satu instrumen pembangunan wilayah yang cukup baik karena dapat menimbulkan beraneka efek atau dampak yang positif terhadap pembangunan wilayah yang ada disekitarnya (Richardson, 1977). Teori ini bermakna suatu daerah dengan banyak industri didalamnya yang menyerap tenaga kerja, seharusnya memberi dampak langsung maupun tidak langsung bagi pembangunan di sekitarnya. Ferroux (2002) berpendapat di dalam suatu proses pembangunan, pertumbuhan ekonomi tidak akan terjadi di seluruh wilayah secara serentak melainkan akan bekerja kearah pengelompokan aktivitas ekonomi yang akhirnya membentuk pusat-pusat pertumbuhan ekonomi. 
Indikator pertumbuhan ekonomi suatu daerah dapat dilihat dari PDRB. Menurut BPS (2020) Produk Domestik Regional Bruto (PDRB) adalah nilai tambah bruto seluruh barang dan jasa yang tercipta atau dihasilkan diwilayah domestik suatu wilayah yang timbul akibat aktivitas ekonomi dalam suatu periode tertentu tanpa memperhatikan apakah faktor produksi yang dimiliki residen atau non residen. PDRB pada dasarnya merupakan jumlah nilai tambah yang dihasilkan oleh seluruh unit usaha dalam suatu daerah tertentu, atau merupakan jumlah nilai barang dan jasa akhir yang dihasilkan oleh seluruh unit ekonomi. PDRB dinilai dalam satuan moneter dan dirinci menurut berbagai kegiatan ekonomi (economic activities) yang membangun perekonomian wilayah yang bersangkutan, seperti: pertanian, pertambangan, industri manufaktur, perdagangan, dan sebagainya.

Menurut Undang Undang Kepabeanan Nomor 17 tahun 2006, Ekspor adalah kegiatan mengeluarkan barang ke luar daerah pabean Indonesia. Daerah Pabean adalah wilayah Republik Indonesia yang meliputi wilayah darat, perairan dan ruang udara diatasnya, serta tempat tempat tertentu di zona ekonomi eksklusif dan landas kontinen yang di dalamnya berlaku Undang-undang kepabeanan. Teori perdagangan internasional mengatakan bahwa suatu negara harus memastikan kebutuhan di dalam negeri terlebih dahulu sebelum mengekspor barang yang dinilai mempunyai keunggulan komparatif ke negara lain. Sebaliknya, untuk memenuhi kebutuhan dalam negeri yang belum mencukupi, negara tersebut akan mengimpornya dari negara lain yang memiliki keunggulan komparatif (Krugman et al., 2018) Teori perdagangan internasional membantu memahami bagaimana perbedaan sumber daya antar negara menimbulkan perdagangan dan mengapa perdagangan tersebut dapat saling menguntungkan.

Nurmawadah (2020) nilai ekspor non migas berpengaruh signifikan terhadap laju pertumbuhan ekonomi di Kalimantan Timur. Ini menunjukkan pengaruh yang cukup besar terhadap pertumbuhan ekonomi Kalimantan Timur apabila ekspor non migas mengalami kenaikan ataupun penurunan. Kim dan Yoo (2016) melakukan pengujian hubungan sebab akibat antara konsumsi batubara dengan pertumbuhan ekonomi di Indonesia untuk periode 1965-2010. Hasil estimasi menunjukkan bahwa terdapat hubungan (kausalitas) dua arah dari konsumsi batubara ke pertumbuhan ekonomi di Indonesia. Hubungan tersebut menyiratkan bahwa peningkatan konsumsi batubara secara langsung merangsang pertumbuhan ekonomi

Penelitian serupa dilakukan untuk melihat hubungan antara konsumsi batubara dan pertumbuhan ekonomi di negara yang berbeda dan hasilnya dapat bervariasi seperti yang dilakukan oleh Chang dkk. (2017) yang menganalisis hubungan sebab akibat antara konsumsi batubara dan pertumbuhan ekonomi di negara-negara BRICS (Brasil, Rusia, India, Cina, dan Afrika Selatan) menggunakan data tahunan dari 1985 hingga 2009. Hasil yang diperoleh menjelaskan bahwa dari kelima negara tersebut memperoleh hasil yang berbedabeda. Untuk Brazil, Rusia, dan Afrika Selatan ditemukan tidak terdapat hubungan sebab akibat antara konsumsi batubara dan pertumbuhan ekonomi. Sebaliknya untuk Cina, hasil yang didapatkan menunjukkan adanya hubungan searah dari 
konsumsi batubara ke pertumbuhan ekonomi Lain halnya dengan India, hasil yang diperoleh menunjukkan terdapat hubungan dua arah antara konsumsi batubara dengan pertumbuhan ekonomi. Jadi untuk Cina dan India, upaya untuk mengurangi penggunaan batubara sebagai sumber energi berpotensi membahayakan pertumbuhan ekonomi.

\section{METODE PELAKSANAAN KEGIATAN}

Jenis data dalam penelitian ini menggunakan data sekunder yang merupakan data runtut waktu (time series). Penelitian ini menggunakan variabel-variabel diantaranya PDRB Kalimantan Timur, Nilai Devisa Ekspor Batubara, Nilai Devisa Ekspor CPO dan Produk Turunannya . Data yang ada diperoleh dari bidang kepabeanan dan cukai Kantor Wilayah Bea Cukai Kalimantan Bagian Timur dan Badan Pusat Statistik dengan variasi bulanan dari tahun 2017 sampai tahun 2021 bulan Juni. Data ekspor CPO pada bulan September 2017 tidak dapat digunakan sehingga jumlah sampel pada penelitian ini ada 53. Data PDRB hanya terdapat dalam variasi triwulanan dan tahunan sehingga penulis mengadopsi metode interpolasi untuk mencari data bulanan yang dibutuhkan. Penurunan ke data bulanan ini diharapkan mampu memenuhi konsistensi data. Penelitian ini mengadopsi metode interpolasi Insukindro (1990) yang menggunakan analogi analisis regresi dengan nilai prediktor dari intercept dan trend dengan $\mathrm{r} 2$ terbaik. Estimasi yang dilakukan secara bertahap diharapkan mampu meningkatkan akurasi prediksi.

Penelitian ini dilakukan dengan metode regresi linier berganda. Analisis data berupa kuantitatif serta pengolahan data menggunakan program SPSS 23. Analisis ini didasarkan kepada rumus berikut:

\section{LOG Y = a + b1LOG X1 + b2LOG X2}

dimana; LOG Y adalah Logaritma natural dari PDRB Kalimantan Timur, LOG X1 merupakan Logaritma natural nilai devisa ekspor CPO dan Produk Turunannya, LOG X2 merupakan Logaritma natural nilai ekspor batu bara.

\section{HASIL DAN PEMBAHASAN}

Tabel 1. Analisis Statistik Deskriptif

\begin{tabular}{cccccc}
\hline & $\mathrm{N}$ & Minimum & Maximum & Mean & Std. Deviation \\
\hline CPO & 53 & 26033451.57 & 321572278.7 & 90614006.4 & 67934174.8 \\
BATU & 53 & 669641199.4 & 1349884553 & 1073506911.8 & 168940793.2 \\
PDRB & 53 & 38763002.33 & 52433928.44 & 42884355.7 & 4144432.5 \\
\hline Sumber: SPSS 23(diolah), 2021
\end{tabular}

Tabel 1 menunjukkan statistik deskriptif dari semua variabel yang digunakan dalam persamaan regresi. Nilai devisa ekspor CPO memiliki rata rata sebesar USD 90614006.45, serta standar deviasi 67934174.854. Nilai minimum dan maksimum dari analisis statistik deskriptif adalah USD 26033452 dan USD 321572279. Nilai rata rata devisa ekspor batu bara sebesar USD 1073506911.87 dengan jangkauan antara USD 66964119 sampai USD 1349884553. Nilai Mean variabel PDRB adalah 4144432.522 dengan nilai terendah 38763002. 
Uji asumsi klasik dilakukan untuk mengetahui apakah model pengujian yang digunakan telah memenuhi ketentuan-ketentuan statistik pada analisis regresi linear berganda. Uji asumsi klasik yang digunakan adalah: heteroskedastisitas, multikolinearitas, autokorelasi, dan normalitas. Dari hasil uji asumsi klasik secara keseluruhan dapat disimpulkan bahwa model regresi telah memenuhi syarat BLUE (Best Linier Unbiased Estimator). Langkah selanjutnya adalah menganalisis hasil regresi. menyajikan ringkasan hasil uji regresi, nilai koefisien determinasi, hasil uji ketetapan model (uji-F), dan hasil uji signifikansi parsial (uji-t).

\begin{tabular}{cccccc}
\multicolumn{6}{c}{ Tabel 2. Hasil Uji Regresi Model Penelitian } \\
\hline Variabel & Koefisien & Std Eror & Beta & $\mathrm{t}$ & Sig \\
\hline CONSTANT & 13502 & 1.293 & & 10.446 & 0.000 \\
LOGX1 & -.068 & .018 & -4.08 & -3.083 & 0.000 \\
LOGX2 & .255 & .058 & .468 & 4.364 & 0.000 \\
\hline R Square & .433 & & & & \\
F Stat & 19.072 & & & & \\
Prob(F Stat) & .000 & & & & \\
\hline Sumber: SPSS 23 (diolah), 2021 & & &
\end{tabular}

Hasil penelitian uji signifikansi parsial (uji-t) menunjukkan ekspor olahan CPO dan ekspor batu bara berpengaruh signifikan terhadap PDRB provinsi Kalimantan Timur dengan signifikansi 0.00 atau di bawah $\alpha=0,05$. Hasil koefisien positif menunjukkan PDRB provinsi Kalimantan Selatan meningkat saat periode ekspor olahan CPO dan batu bara naik. Guna mengetahui variasi keterkaitan variabel independen secara keseluruhan dianalisis melalui nilai koefisien diterminan (R2). Selanjutnya juga dapat diketahui apakah semua variabel independen berpengaruh terhadap variabel dependen, maka dilakukan dengan uji F. Hasil analisis regresi memberikan pengertian bahwa nilai devisa ekspor CPO dan batubara secara simultan berpengaruh terhadap PDRB Kalimantan Timur. Ini dibuktikan dengan uji $\mathrm{F}$ dengan nilai signifikansi 0.000 atau di bawah $\alpha=0,05$. Sementara itu nilai R Square sebesar 0.433 menunjukan bahwa ekspor kedua komoditas ini berkontribusi terhadap 43.3\% PDRB Kalimantan Timur atau masih banyak variabel lain diluar penelitian. Hasil ini bisa diprediksi karena banyak faktor lain yang mempengaruhi perekonomian di daerah Kalimantan Timur selain dari devisa ekspor.

Rumusan masalah yang pertama adalah mencari tahu apakah ekspor olahan CPO dan batu bara memberi dampak pada peningkatan PDRB di Kalimantan Timur. Berdasarkan hasil analisis regresi kedua variabel ini secara simultan berpengaruh terhadap peningkatan PDRB. Hal ini memberi gambaran pentingnya mendorong ekspor kedua komoditas ini untuk lebih menghidupkan perekonomian di Kalimantan Timur. Disini peran Bea Cukai dalam mengasistensi perusahaan menjadi penting. Bea cukai harus menjadi katalisator untuk mempercepat ekspor pada industri hilir. KWBC Kalbagtim saat ini sudah banyak memberi fasilitas kepada perusahaan pada kedua sektor ini di Kalimantan Timur. Menurut data bidang fasilitas dan perizinan berikut ada 3 perusahaan mendapat fasilitas Gudang Berikat, 10 perusahaan Pusat Logistik Berikat (PLB), 4 perusahaan Kawasan 
Berikat dan 2 perusahaan KITE. Pemerintah melalui Bea Cukai berinvestasi dengan memberi fasilitas ini. Perusahaan harus berkomitmen dalam memberi nilai tambah dengan kemudahan yang sudah diberikan. Perusahaan harus menyadari peran pentingnya pembangunan ekonomi dan sosial bagi lingkungan sekitar operasional perusahaan. Peran Perusahaan dalam pembangunan berkelanjutan menjadi komitmen yang selalu diimplementasikan guna memajukan dan mengembangkan potensi masyarakat sekitar. Tanggung jawab ekonomi dan sosial perusahaan merupakan kebijakan yang diambil guna menemukan titik keseimbangan antara perusahaan dan pihak yang terkait seperti masyarakat, pemerintah dan konsumen. Dalam hal ini perusahaan bukan saja mencari keuntungan, akan tetapi juga memperhatikan dampak ekonomi dan sosial apa yang bisa ditimbulkan dengan keberadaan investasi perusahaan.

Hasil penelitian berikutnya menunjukkan secara parsial kedua komoditas memberikan pengaruh yang signifikan terhadap peningkatan PDRB. Menurut data yang ada ekspor olahan CPO dan batu bara dapat mengamplifikasi perekonomian daerah dengan PDRB sebagai indikatornya. Ekspor CPO yang selama ini jelas memberikan penerimaan negara tidak menjadi syarat mutlak yang memberi pengaruh ke PDRB. Dengan kata lain nilai ekspor yang tinggi malah lebih memberikan dampak. Nilai koefisien batubara yang lebih tinggi memberikan pengertian bahwa kenaikan ekspor komoditas ini lebih berdampak ke peningkatan PDRB. Dari hasil ini memberikan gambaran agar pemerintah melalui Bea Cukai bisa lebih memberikan perhatian ke industri yang mempunyai nilai devisa yang tinggi seperti batu bara. Menurut data dari bidang fasilitas dan perizinan masih sedikit perusahaan batu bara yang mendapat fasilitas. Bea Cukai bisa mendorong dan menginisiasi perusahaan untuk mendapatkan fasilitas ini. Kemudahan yang diperoleh tentu akan memiliki efek yaitu meningkatkan PDRB yang artinya mendukung kemajuan ekonomi masyarakat sekitar. Akan tetapi fasilitas yang diberikan harus diiringi pengawasan yang optimal.

\section{KESIMPULAN}

batu bara berpengaruh signifikan terhadap PDRB provinsi Kalimantan Timur dengan signifikansi 0.000. Hasil di atas mengungkapkan bahwa untuk dapat meningkatkan pertumbuhan ekonomi regional maka dibutuhkan peningkatan kinerja ekspor, terutama yang mempunyai nilai ekspor yang tinggi. Menurut hasil penelitian dari data yang ada ekspor olahan CPO dengan Bea Keluar yang tinggi tidak menjamin peningkatan PDRB. Hal ini sesuai dengan teori yang dikemukakan oleh Smith mengenai Teori Keunggulan Absolut yang membuktikan bahwa semakin tinggi output maka akan mengakibatkan tingginya volume ekspor dan memberikan kontribusi terhadap PDRB. Peningkatan kinerja ekspor dapat dilakukan dengan berbagai cara, salah satunya adalah dengan perbaikan sistem administrasi ekspor, peningkatan riset dan pengembangan produk, peningkatan sarana dan prasarana infrastruktur dan perluasan pasar internasional. Peran Bea Cukai dalam mendukung ekspor kedua komoditas ini terutama di wilayah 
Kalimantan Timur menjadi krusial dalam peningkatan volume ekspor yang pada akhirnya meningkatkan perekonomian regional.

\section{DAFTAR PUSTAKA}

Babić, A. (2007). Paul R. Krugman, Maurice Obstfeld: International Economics: Theory and Policy. Financial Theory and Practice, 31(3), 317-318.

Chang, T., Deale, D., Gupta, R., Hefer, R., Inglesi-Lotz, R., \& Simo-Kengne, B. (2017). The causal relationship between coal consumption and economic growth in the BRICS countries: Evidence from panel-Granger causality tests. Energy Sources, Part B: Economics, Planning and Policy, 12(2), 138-146. http://doi.org/10.1080/15567249.2014.912696

Insukindro. (1990). Penurunan Data Bulanan dari Data Tahunan. Economics and Finance in Indonesi, 38(4).

Kim, H. M., \& Yoo, S. H. (2016). Coal consumption and economic growth in Indonesia. Energy Sources, Part B: Economics, Planning and Policy, 11(6), 547-552. http://doi.org/10.1080/15567249.2012.690503

Mankiw, N. G. (2003). Teori Makro Ekonomi Terjemahan. Jakarta: PT. Gramedia Pustaka Utama.

Nurmawaddah, S. (2019). Pengaruh ekspor non migas terhadap pertumbuhan ekonomi provinsi kalimantan timur Effect of non-oil and gas exports on economic growth east kalimantan province. Akuntabel, 16(1), 128-133. Retrieved from http://journal.feb.unmul.ac.id/index.php/AKUNTABEL/article/download/53 $84 / 489$

Odling-Smee, J. C., \& Richardson, H. W. (1975). Input-Output and Regional Economics. Economica, 42(165), 104. http://doi.org/10.2307/2552995

Timmory. (2021). Rekor Ekspor Produk Sawit bulan Mei Tertinggi dalam Sejarah. https://ekonomi.bisnis.com/read/20210714/12/1417742/rekor-eksporproduk-sawit-mei-tertinggi-sepanjang-sejarah 